\title{
Studies on Performance of Softwood Grafting in Guava (Psidium guajava L.) cv. Sardar as Influenced by Different Shade Intensity
}

\author{
B. Manga* and P. Jholgiker \\ Department of Fruit science, KRCCH, Arabhavi, University of Horticultural Sciences, \\ Bagalkot, Karnataka, India \\ *Corresponding author
}

\section{A B S T R A C T}

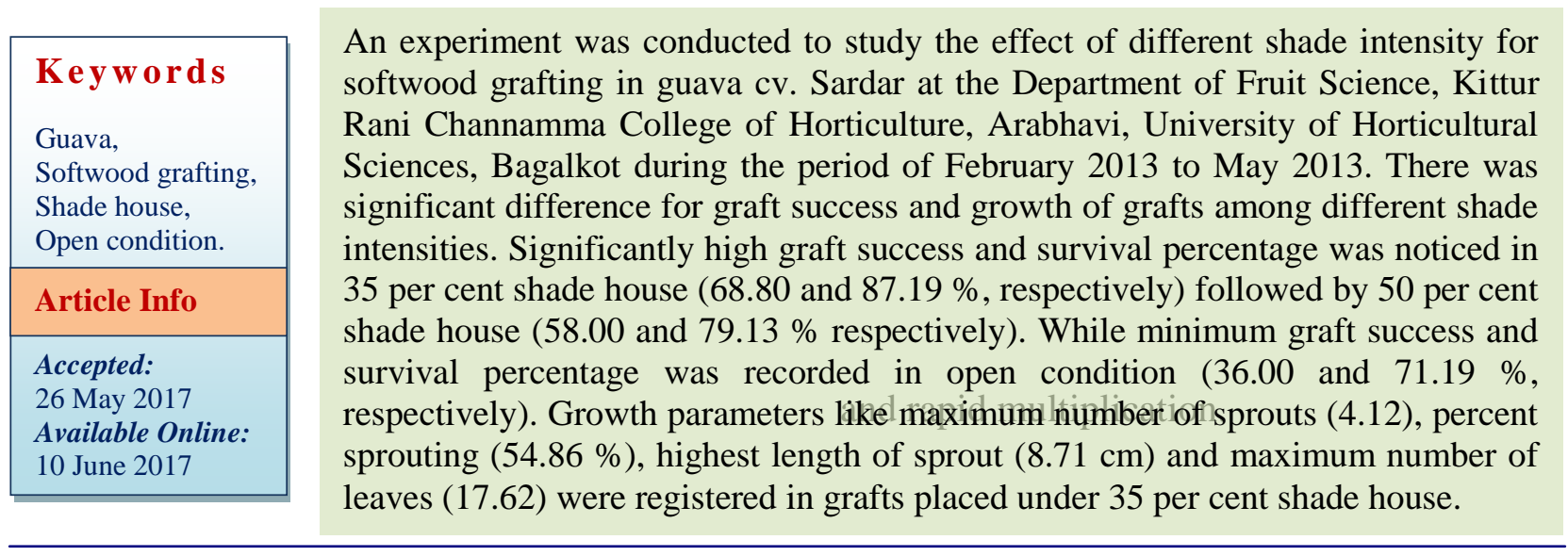

\section{Introduction}

Guava is considered as one of the exquisite and nutritionally valuable fruit crops. It excels most other fruit crops in productivity, hardiness, adaptability and nutritive value. Besides its high nutritive value, it bears heavy crop every year and gives good economic returns involving very little input (Singh, 2007). Most of guava plantations in India are seedling origin. Traditionally, it is mostly propagated from seed (Zamir et al., 2003). However, plants raised from seeds are not true to type and eventually take longer time to reach to bearing stage. They are also propagated by layering, however it is combursome and has limitation for large scale
At present, softwood wedge grafting is very popular in many fruit crops like jamun (Mulla et al., 1991), sapota (Pampanna and Sulikeri, 2000) and custard apple (Ghosh et al., 2004). Little information is available softwood grafting of guava. This method is easy, convenient in handling, involves simple skill and takes short period. The most important feature of the method is that, it allows higher rate of multiplication of plants and resultant plants will be vigorous. The propagation environment for grafting is one of the most important factors which plays a key role in success of grafting. Shade nets provide cheap, 
simple and very effective closed environment for the propagation of plants.

The new technology of different shade intensity nets promotes stimulation of many desirable physiological responses which are light regulated. Growing stock plants in less than full sunlight increased growth attributes. Some of review of literatures shown that low shade intensity environment can increase growth of grafts/ plants. However, there are no reports exist concerning softwood grafting of guava in different shade intensity. There is a need to known optimum shade intensity good for improved higher propagation efficiency. The study evaluated the influence of shade intensity on softwood grafting in guava cv. Sardar. Therefore, the present investigation was undertaken.

\section{Materials and Methods}

An experiment, Studies on performance of softwood grafting in guava cv. Sardar as influenced by different shade intensity was carried out during the period from February 2013 to May 2013, at the Department of Fruit Science, Kittur Rani Channamma College of Horticulture, Arabhavi, University of Horticultural Sciences, Bagalkot, Karnataka state. The experiment was conducted to find out the influence of shade intensity on success of softwood grafting in guava. The experiment was laid out in Randomized Block Design with 4 treatments and 5 replications. Softwood wedge grafting was performed in the month of February. Four hundred grafts were prepared at the rate of hundred grafts in each treatment and placed under different shade intensity viz., open condition (control), 35 per cent shade house, 50 per cent shade house and 75 per cent shade house.

Root stocks were raised in poly bags from fresh seeds of guava cv. 'Sardar' extracted from ripe fruits for approximately 6 to 8 months till they attained a stem diameter of 0.5 to $1.0 \mathrm{~cm}$. The scion shoots $(15$ to $18 \mathrm{~cm}$ long) of pencil size thickness with 3 to 4 healthy buds were used for grafting. Selected scion shoots were pre-cured ten days prior to detachment. Softwood wedge grafting was performed in the month of February as per procedure suggested by Amin (1974). The prepared grafts were covered from top by polytube cap. This cap was retained on the graft for one month or till sprouting was observed on the graft. The observation were recorded on graft-take i.e. per cent graft success and survival percentage. The growth parameters such as number of sprouts, per cent sprouting, average length of sprout and average number of leaves were recorded at 30, 60 and 90 days after grafting. The data was statistical analysed by following procedure as suggested by Panse and Sukhatme (1967).

\section{Results and Discussion}

The major environmental conditions are light, humidity and temperature. Which influence success of grafting, survival and post growth behavior of grafts. Shade house protect the grafts/ plants from high temperature and high light intensity as a resulted reduce moisture stress and decrease the water requirement of plant. In generally a temperature range of 15 $30^{\circ} \mathrm{C}$ considered ideal for good cambial contact and for rapid growth of the cambial cells under shade house condition, there is rigid control over temperature and relative humidity (Sharma and Srivastav, 2004).

The data pertaining to the studies on performance of softwood grafting in guava cv. Sardar as influenced by different shade intensity on graft-take demonstrated varying degree of success (Table 1). Interpretation of data indicated maximum per cent graft success $(68.80 \%)$ was recorded in graft kept under 35 per cent shade house followed by 50 per cent shade house $(58.00 \%)$ and lowest grafting success was recorded in open 
condition $(36.00 \%)$ at 90 days after grafting respectively.

Results of data reveal significant differences for graft survival in differ with respective shade intensity. The significantly maximum graft survival $(87.19 \%)$ was recorded in grafts placed under 35 per cent shade house followed by graft under the 50 per cent shade house condition $(79.13 \%)$ at 90 days after grafting (Table 1). The superiority of propagation with help of shade souse has been well documented by Selvi et al., (2008) in jack fruit and Shashikumar (2010) in guava. The beneficial effect of high graft success for softwood grafting under 35 per cent shade house due to the prevailing optimum, minimum and maximum temperatures with least disparity coupled with higher humidity experienced. During the early stages of graft union maximum light intensity provide enough energy for callus formation and further growth of grafts. The grafts exposed to high light intensity to increase carbohydrates production by photosynthesis (Hartman and Kester, 1972). Similar findings were also reported by Sappandi et al., (2006) in wood apple.

Table.1 Effect of different shade intensity on graft-take and its growth at 90 DAG in softwood grafting of guava cv. Sardar

\begin{tabular}{|ccccccc|}
\hline Treatment & $\begin{array}{c}\text { Per cent } \\
\text { graft } \\
\text { success }\end{array}$ & $\begin{array}{c}\text { Number of } \\
\text { sprouts }\end{array}$ & $\begin{array}{c}\text { Per cent } \\
\text { sprouting }\end{array}$ & $\begin{array}{c}\text { Average } \\
\text { length of } \\
\text { sprout }(\mathbf{c m})\end{array}$ & $\begin{array}{c}\text { Average } \\
\text { number } \\
\text { of leaves }\end{array}$ & $\begin{array}{c}\text { Survival } \\
\text { percentage }\end{array}$ \\
\hline 35 per cent shade house & 68.80 & 4.12 & 66.84 & 8.71 & 17.62 & 87.19 \\
& $(56.04)^{*}$ & & $(54.86)$ & & & $(77.95)$ \\
50 per cent Shade house & 58.00 & 3.24 & $\begin{array}{c}58.63 \\
(49.98)\end{array}$ & 6.71 & 13.70 & 79.13 \\
& $(49.60)$ & & & & $(62.83)$ \\
50 per cent Shade house & 49.00 & 3.16 & 54.80 & 7.88 & 12.98 & 78.33 \\
& $(44.43)$ & & $(47.75)$ & & & $(62.27)$ \\
control & 36.00 & 2.63 & 49.80 & 7.33 & 11.64 & 71.19 \\
& $(36.87)$ & & $(44.89)$ & & & $(57.57)$ \\
& 3.20 & 0.23 & 2.60 & 0.29 & 1.12 & 2.43 \\
SEm & 9.85 & 0.70 & 7.88 & 0.88 & 3.45 & 7.59 \\
CD $9 \%$ & 13.50 & 15.50 & 9.94 & 8.33 & 15.73 & 6.95 \\
\hline
\end{tabular}

DAG - Days after grafting

* Values in parenthesis are angular transformation data

Least graft success and survival was noticed in the open condition. This may be attributed uncontrolled temperatures, fluctuations in day and night temperatures, low levels of relative humidity and sunlight has pronounced effects on the production of callus tissues, higher temperatures retard the callus production and faster desiccation of scion shoots more apparent as the temperatures increase until death of the cells occurred at higher temperature (Jacob et al., 2001). This fact has been well documented in other fruit crops like guava Singh et al., (2011), Desai and Patil (1984) in mango, Pampanna and Sulikeri (1994) in sapota, Swamy et al., (1990) in cashewnut and Selvi et al., (2008) in jackfruit..

The post grafting growth behavior of grafts may be attributed to the physic-chemical condition of the scion shoots. February was the best month for softwood grafting in guava. This could be due to better physiological condition of both the scion and 
the stock. It is known that plants start a new growth flush after a long period of dormancy in the month of February. This may have resulted in good sap flow and cambial activity. This trend was also observed by Kelaskar et al., (1991) and Pampanna and Sulikeri (1994) in sapota.

\section{References}

Amin, R. S. 1974. A study on the establishment of mango orchard with wedge graft on in-situ grown mango seedlings in dry region of Gujarat. Haryana J. Hort. Sci. 3: 160-167.

Desai, J. B. and Patil, V. I. C., 1984, Success of stone grafting in mango in glass house and in open condition. Punjab Hort. J., 24: 7-10.

Ghosh, S. N., Manna, S. and Mathew, B., 2004, Effect of season on success of grafting in custard apple under semi-arid condition of West Bengal. Hort. J., 17 (1): 89-91.

Hartman, H. T. and Kester, D. E., 1972, Plant propagation principles and practices. Pretence Hall of India Ltd., New Delhi, $2^{\text {nd }}$ Ed. (Revised), Pp.197-252.

Jacob, S., Ray, D. P., Sathu, G. S. and Chandra, A., 2001, Studies on the success of softwood grafting of some commercial hybrid mango (Mangifera indica L.). Orissa J. Hort., 29: 6-8.

Kelaskar, A. J., Desai, A. G. and Salvi, M. J., 1991, Effect of rootstock leaf retention, shade and tying material on patch bud grafts of jackfruit. Indian J. Pl. Physio., 34: 58-62.

Mulla, B. R., Angadi, S. G., Mathad, J. C., Patil, V. S. and Mummigatti, U. V., 2011, Studies on softwood grafting in jamun (Syzygium cumini Skeels.). Karnataka J. Agric. Sci., 24 (3): 366-368.

Pampanna, Y. and Sulikeri, G. S., 1994, Effect of weather condition on the success of softwood grafting in sapota. South Indian
Hort., 42:303-308.

Panse, V. G. and Ukhatne, P. V., 1967, Statistical methods for agricultural workers, ICAR, New Delhi, pp. 152-161.

Sappandi, S., Athani, S. I., Duragannavar, M. P., Adiga, J. D., Swamy, G. S. K., Hiremath, J. R. and Patil, P. B., 2006, Effect of season and genotypes on sprout height of wood apple grafts under polyhouse and shade house conditions. J. Asian Hort., 2 (4): 287290.

Selvi, R., Kumar, N., Selvarajan, M. and Anbu, S., 2008, Effect of environment on grafting success in jackfruit. Indian J. Hort., 65 (3): 341-343.

Sharma, R. R. and Srivastav, M., 2004, Plant propagation \& nursery management. First Edition, International book distributing co., Charbagh, Lucknow.

Shashikumar, 2010, Standardization of softwood grafting in guava (Psidium gujava L). M. Sc. (Hort.) Thesis, Univ. Agric. Sci., Dharwad.

Singh, G., 2007, Recent development in production of guava. Acta Hort., 735: 161176.

Srinivasn, K., 1970, Studies on vegetative propagation of jackfruit (Artocarpus heterophyllus Lam.). Agric. J. Kerala., 8: 51-52.

Swamy, K. R. M., Singh, R. and Mohan, E., 1990, Correlation of success in softwood grafting of cashew with weather parameters. South Indian Hort., 38:297-300.

Zamir, R., Khattak, G. S. S., Mohammad, T. and Ali, N., 2003, in vitro mutagenesis in guava (Psidium guajava L.). Pakistan J. Bot., 35 (5): 825-828.

Singh, G., Pandey, S. and Singh, K., 2011, Vegetative propagation of guava through wedge grafting. Prog. Hort., 43 (2): 203210 .

\section{How to cite this article:}

Manga, B. and Jholgiker, P. 2017. Studies on Performance of Softwood Grafting in Guava (Psidium guajava L.) cv. Sardar as Influenced by Different Shade Intensity. Int.J.Curr.Microbiol.App.Sci. 6(6): 2792-2795. doi: https://doi.org/10.20546/ijcmas.2017.606.332 
Int.J.Curr.Microbiol.App.Sci (2017) 6(6): 2792-2795 